\title{
Evaluation of the Sporting Situation and Emotional Intelligence Levels of Different Occupation Groups
}

\author{
Murat Sarıkabak \\ Correspondence: Faculty of Sport Science, Bartın University, Bartın, Turkey
}

Received: May 5, $2019 \quad$ Accepted: May 31, $2019 \quad$ Online Published: June 17, 2019

doi:10.11114/jets.v7i8.4330 URL: https://doi.org/10.11114/jets.v7i8.4330

\begin{abstract}
The contribution of the physiologic and cognitive processes is important for increasing the quality of the education and occupational productivity. The new researches done indicate that exercising frequency and emotional intelligence level have precious contributions on the occupational performances of the individuals. The purpose of this research was determined as evaluating the sporting situation and emotional intelligence levels of adults in different occupational groups. 586 individuals participated in the research, who works in various professions in Bartın Province. The information on the participant group and the other variables of the research was analyzed via descriptive statistic techniques. For evaluating the data, SPSS 21.0 package software was used and for analyzing the data, descriptive statistics, independent t-test and one-way variance analysis (ANOVA) techniques were used. As a result of the data obtained, no significant difference was encountered in the emotional intelligence sub-dimensions and total scores depending on the sporting situation of the participants $(p>0.05)$. As a result of the analyses done for the gender variable, significant differences were obtained on behalf of the women and it was seen that emotional intelligence total scores of the female workers are higher compared with the male workers $(p<0.05)$. For the finding where the relations between age variable and emotional intelligence was evaluated, it was seen that there is a significant decrease in the emotional intelligence level with the increase in age $(\mathrm{p}<0.05)$. This decrease was tried to be explained with occupational exhaustion. At the same time, the finding was arrived that the total emotional intelligence scores of the participants who work as teacher, compared with the other professions, is higher with a significant level compared with the other profession groups $(\mathrm{p}<0.05)$. The findings of the research were discussed in the light of the literature and recommendations were offered for contributing to the new researches to be made.
\end{abstract}

Keywords: emotional intelligence, sports, occupation, teacher

\section{Introduction}

The place of executing the professions with high performance is big in maintaining the human life healthily and meeting all needs required by the society (Seçer, 2007: 3). While the productivity of a worker working in a factory contributes to the quality and number of the product, the productivity of a teacher is very important for growing healthy generations. The occupational productivity is observed in the performance and the outputs specific to the profession, had, while especially economic and environmental conditions and health cause that these outputs are at the requested level. Being physiologically strong, feeling well psychologically and having a peaceful live may have contributions to the productivity (Vurucu, 2010: 1). The speed indicated when solving a problem specific to the profession may be related with the experience enabling the efficient usage of the resources and strength indicated for long times, the frequency of sportive activity and the emotional intelligence.

Sportive activities consist of movements paving the ground for being healthy physiologically. These movements, when done at a certain frequency and levels, may positively affect the person socially and psychologically. A lot of researches are being done on the positive effects of the sports on the individuals. While some of the researches focus on obesity, considered as one of the biggest health problems of the age, some focuses on the effects of the sports on the human psyche (Rahman, Sugiyanto and Kristiyanto, 2018; Szabo, Griffiths and Demetrovics, 2019; Menevse, 2018; Thapa et al., 2018; Maguire, 2018). In conclusion it can be said that sport activities have positive contributions to the performance of a person in the business and private life.

Another subject, on which a lot of researches done, like sports, focused on the intelligence researches. The increase in the researches done in all profession and science branches, especially by caring for the emotional intelligence notion by 
the scientists, analyzes the emotional intelligence with respect to its effect on the performance. In the literature, usually researches are encountered with, which were done on many fields such as health (Littlejohn, 2012), education (Corcoran and Tormey, 2012), entrepreneurship (Cole, Cox and Stavros, 2018), engineering (Kosti, Feldt and Angelis, 2014), and sports (Zizzi, Deaner and Hirschhorn, 2003).

Even though the factors contributing to the high performance and productivity are very general, Sarikabak (2018: 406) stated that sports and emotional intelligence may have an important contribution on the performance. The same researcher, in an another research (Sarıkabak et al., 2018: 163) stated that the increase in the emotional intelligence level has a negative oriented relation with the academic postponing behavior and as the emotional intelligence increases, academic postponing decreases. Paul (2015: 3) stated that the increase in the sports and emotional intelligence level may have contribution to the personality development and revealed that the emotional intelligence, especially in women, has a negative oriented relationship with neuratism. Karademir and Çoban (2011: 38) said that individuals having high emotional intelligence level may positively affect the performance of the trainers and athletes.

The emotional intelligence notion, for which Mayer and Salovey (1990) had a contribution for defining with an academic assay, can be defined as a process starting from a person knowing all persons and situations, with which he is in contact, well. Emotional intelligence has become a more known notion with the book called 'Emotional Intelligence' written by Daniel Goleman. Goleman (1996: 68) defined the emotional intelligence notion as the person being able to understand his/her feelings, affect the persons in his circle socially and manage his feelings in the professional sense. This process develops after the person's self-consciousness, empathy ability and professional management of the emotions. Bar-on, who had important contributions to the emotional intelligence researches, (2005: 48) defined the emotional intelligence as the people successfully overcoming the positive and negative situations they encounter with in their social lives. Bar-on said that emotional intelligence also has relationship with the personal, emotional, social adequacy and skills.

People are in the pursuit for obtaining any profession and performing this profession in all their lives. The attitude of the individuals, with high emotional intelligence level, against their professions may change positively (Goleman, 1996). It is expected that the individuals, when performing their professions, do the duties, incumbent on them, with a top level performance. Reaching this top level performance may be related with the sporting situation of the individuals. The positive effects, created by sports physiologically and psychologically, would be effective on the individuals executing their professions. This situation was included inside the sporting commission report and makes it mandatory that the institutions and organizations in Turkey make sports facilities and organizations (Aktürk, 1983). With the new researches made, it can be said that sportive activity and emotional intelligence level have precious contributions on the professional performances of the individuals. Therefore, the purpose of this research was determined as assessing the playing sports situation and emotional intelligence levels of individuals from different profession groups.

\section{Method}

\subsection{Research Model}

The research made was performed by taking the relational screening model with respect to the target and scope it tends to. The relational screening models are the researches where the relationship between two or more variables is evaluated without intervening to the variables (Büyüköztürk et al., 2017: 27).

\subsection{Population and Sample}

586 participants, in total, accessed to, who live in Bartın Province of Turkey in the scope of the research made. The participants were selected via simple random method from nine different occupation groups. The occupations were determined by taking the opinion of expert among the occupations which are considered as having the most interaction with people, for serving the society. These occupations consist of artisans, drivers, workers, religious officials, security personnel, healthcare personnel, workers of auto industry, pre-school teacher, and special training teachers.

\subsection{Data Collection Tools}

\subsubsection{Personal Information Form}

The personal information form, issued by the researcher, consists of the questions prepared for determining the workers' gender, age, sporting situation, and professions.

\subsubsection{Schutte Emotional Intelligence Scale}

Schutte emotional intelligence scale for measuring the emotional intelligence the Schutte emotional intelligence scale was used, which was developed by Schutte et al., (1998), revised by Austin, Saklofske, Huang, and McKenney (2004) and adapted to Turkish by Tatar, Tok and Saltukoğlu (2011). The articles in the measurement tool are answered by using the 5 digit answer key. The scale consists of 41 articles. At the same time, the scale consists of three sub-dimensions as 
"optimism-regulating the mood", "using the feelings" and "evaluation of the emotions". In the reliability analysis done for the measurement tool, Cronbach's Alpha reliability coefficient was taken as .85 .

\subsection{Data Analysis}

For analyzing the data, the information belonging to the participant group and the other variables of the research was analyzed via descriptive statistic techniques. For analyzing the data, independent t-test and one-way variance analysis (ANOVA) techniques were used. The significance level of the data was taken as $(\mathrm{p}<0.05)$. For evaluating the data, SPSS 21.0 package software was used.

\section{Results}

Table 1. The distribution of the participants on gender, age group, sporting situation, and profession groups

\begin{tabular}{|c|c|c|}
\hline Gender & $\mathbf{N}$ & $\%$ \\
\hline Male & 392 & 66,9 \\
\hline Female & 194 & 33,1 \\
\hline Age groups & $\mathbf{N}$ & $\%$ \\
\hline $18-23$ & 76 & 13,0 \\
\hline $24-29$ & 169 & 28,8 \\
\hline $30-35$ & 128 & 21,8 \\
\hline $36-41$ & 85 & 14,5 \\
\hline $42-47$ & 66 & 11,3 \\
\hline 48-üstü & 62 & 10,6 \\
\hline Sporting situation & $\mathbf{N}$ & $\%$ \\
\hline Sporting & 139 & 23,7 \\
\hline Not-sporting & 447 & 76,3 \\
\hline Profession groups & $\mathbf{N}$ & $\%$ \\
\hline Artisan & 61 & 10,4 \\
\hline Driver & 76 & 13,0 \\
\hline Religious officials & 70 & 11,9 \\
\hline Worker & 79 & 13,5 \\
\hline Security personnel & 64 & 10,9 \\
\hline Healthcare personnel & 68 & 11,6 \\
\hline Auto Industry worker & 72 & 12,3 \\
\hline Preschool teacher & 46 & 7,8 \\
\hline Special education teacher & 50 & 8,5 \\
\hline Total & 586 & 100,0 \\
\hline
\end{tabular}

According to the Table 1, it was seen that 392 of the participants (66.9) are male and 194 (33.1\%) female. Considering the distribution of the participants according to the age groups, it was found out that 76 of them $(13.0 \%)$ are in the age group $18-23,169(28.8 \%)$ in the age group $24-29,128(\% 21.8)$ in the age group $30-35,85(14.5 \%)$ in the age group $36-41,66(11.3 \%)$ in the age group $42-47$, and $62(10.6 \%)$ in the age group 48 and over. Considering the sporting situation of the participants, it was found out that 139 (23.7\%) are the sporting individuals, 447 (76.3\%) non-sporting. On the other hand, it was seen that 61 of the participants $(10.4 \%)$ are artisans, $76(13.0 \%)$ drivers, $70(11.9 \%)$ religious officials, $79(13.5 \%)$ workers, 64 (10.9\%) security personnel, 68 (11.6\%) healthcare personnel, 72 (12.3\%) auto industry worker, $46(7.8 \%)$ preschool teacher, and $50(8.5 \%)$ special education teachers. 
Table 2. T-Test results of the emotional intelligence scores of the participants according to gender

\begin{tabular}{|c|c|c|c|c|c|c|}
\hline & Gender & $\mathrm{N}$ & $X$ & SS & $\mathrm{t}$ & $\mathrm{p}$ \\
\hline \multirow{2}{*}{$\begin{array}{l}\text { Optimism/regulating the } \\
\text { mood }\end{array}$} & Male & 392 & 41,62 & 5,72 & \multirow[t]{2}{*}{$-5,18$} & \multirow[t]{2}{*}{, 00} \\
\hline & Female & 194 & 44,19 & 5,43 & & \\
\hline \multirow[t]{2}{*}{ Using the feelings } & Male & 392 & 13,65 & 1,66 & \multirow[t]{2}{*}{$-1,58$} & \multirow[t]{2}{*}{, 11} \\
\hline & Female & 194 & 13,87 & 1,54 & & \\
\hline \multirow[t]{2}{*}{ Evaluating the feelings } & Male & 392 & 23,35 & 2,26 & \multirow[t]{2}{*}{$-2,70$} & \multirow[t]{2}{*}{,00 } \\
\hline & Female & 194 & 23,90 & 2,38 & & \\
\hline \multirow{2}{*}{$\begin{array}{l}\text { Total emotional intelligence } \\
\text { score }\end{array}$} & Male & 392 & 116,80 & 10,01 & \multirow[t]{2}{*}{$-5,62$} & \multirow[t]{2}{*}{, 00} \\
\hline & Female & 194 & 121,78 & 10,24 & & \\
\hline
\end{tabular}

Considering the Table 2, t-test was applied for comparing the emotional intelligence scores of the participants. A statistically significant difference, on behalf of the females, was found out in the optimism/regulating the mood, evaluating the feelings and total emotional intelligence score according to the results.

Table 3. T-test results of the emotional intelligence scores of the participants according to the sporting situation.

\begin{tabular}{|c|c|c|c|c|c|c|}
\hline & Sporting situation & $\mathrm{N}$ & $\mathrm{X}$ & $\mathrm{SS}$ & $\mathrm{t}$ & $\mathrm{p}$ \\
\hline \multirow{2}{*}{$\begin{array}{l}\text { Optimism/regulating the } \\
\text { mood }\end{array}$} & Non-sporting & 447 & 42,37 & 5,73 & \multirow[t]{2}{*}{,- 77} & \multirow[t]{2}{*}{,43 } \\
\hline & Sporting & 139 & 42,80 & 5,82 & & \\
\hline \multirow[t]{2}{*}{ Using the feelings } & Non-sporting & 447 & 13,72 & 1,58 & \multirow[t]{2}{*}{, 10} & \multirow[t]{2}{*}{,91 } \\
\hline & Sporting & 139 & 13,71 & 1,77 & & \\
\hline \multirow[t]{2}{*}{ Evaluating the feelings } & Non-sporting & 447 & 23,53 & 2,33 & \multirow[t]{2}{*}{,- 06} & \multirow[t]{2}{*}{,94 } \\
\hline & Sporting & 139 & 23,54 & 2,28 & & \\
\hline \multirow{2}{*}{$\begin{array}{l}\text { Total emotional intelligence } \\
\text { score }\end{array}$} & Non-sporting & 447 & 118,28 & 10,34 & \multirow[t]{2}{*}{,- 71} & \multirow[t]{2}{*}{47} \\
\hline & Sporting & 139 & 119,00 & 10,37 & & \\
\hline
\end{tabular}

Considering the Table 3, the t-test was applied for comparing the emotional intelligence scores according to the sporting situation of the participants. No statistically significant difference was found out in the emotional intelligence sub-dimensions and total score according to the sporting situation of the participants $(\mathrm{p}>0.05)$.

Table 4. Results of the one way variance analysis of the emotional intelligence scores of the participants according to the age groups

\begin{tabular}{|c|c|c|c|c|c|c|c|}
\hline & & $\begin{array}{c}\text { Total } \\
\text { squares }\end{array}$ & $\mathrm{Sd}$ & $\begin{array}{l}\text { Squares } \\
\text { Average }\end{array}$ & $\mathrm{F}$ & $\mathrm{p}$ & Diff. \\
\hline \multirow{4}{*}{$\begin{array}{l}\text { Optimism/regulating the } \\
\text { mood }\end{array}$} & Inter-groups & 229,62 & 5 & 45,92 & 1,39 & ,22 & - \\
\hline & In-group & 19150,49 & 580 & 33,01 & & & \\
\hline & Total & 19380,11 & 585 & & & & \\
\hline & Inter-groups & 63,24 & 5 & 12,64 & 4,91 & , 00 & $1>5$ \\
\hline \multirow[t]{2}{*}{ Using the feelings } & In-group & 1491,52 & 580 & 2,57 & & & $2>3,5$ \\
\hline & Total & 1554,76 & 585 & & & & \\
\hline \multirow[t]{4}{*}{ Evaluating the feelings } & Inter-groups & 86,08 & 5 & 17,21 & 3,26 & ,00 & $2>6$ \\
\hline & In-group & 3059,66 & 580 & 5,27 & & & \\
\hline & Total & 3145,74 & 585 & & & & \\
\hline & Inter-groups & 1462,62 & 5 & 292,52 & 2,77 & ,01 & $2>6$ \\
\hline \multirow{2}{*}{$\begin{array}{l}\text { Total emotional } \\
\text { intelligence score }\end{array}$} & In-group & 61184,81 & 580 & 105,49 & & & \\
\hline & Total & 62647,43 & 585 & & & & \\
\hline
\end{tabular}
1. 18-23,
2. 24-29,
3. 30-35,
4. 36-41,
5. $42-47, \quad 6.48$ and over 
Considering the Table 4, one way variance (ANOVA) analysis was applied for comparing the age groups of the participants according to the emotional intelligence scores. According to the results, it was seen that there is a statistically significant difference in the using the feelings, evaluating the feelings and total emotional intelligence score according to the age groups $(\mathrm{p}<0.05)$. According to the results of the Post Hoc (TUKEY) test, performed for determining the significant difference is between which groups, a statistically significant difference was found out between age group $18-23$ and age group $42-47$ in the using the feelings sub-dimension on behalf of the age group 18 -23 , between the age group $24-29$ and age groups $30-35$ and $42-47$, on behalf of the age group $24-29$ ( $p<0.05$ ). In the evaluating the feelings sub-dimension, a statistically significant difference was found out between the age group $24-29$ and age group 48 and over, on behalf of the age group $24-29(\mathrm{p}<0.05)$. On the other hand, a statistically significant difference was found between the age group $24-29$ and age group 48 and over, on behalf of the age group $24-29$ in the total emotional intelligence score $(\mathrm{p}<0.05)$. No statistically significant difference was found out in the optimism sub-dimension ( $\mathrm{p}>0.05$ ).

Table 5. Results of the one way variance analysis of emotional intelligence scores of the participants according to the profession groups

\begin{tabular}{|c|c|c|c|c|c|c|c|}
\hline & & Total squares & $\mathrm{Sd}$ & $\begin{array}{l}\text { Squares } \\
\text { Average }\end{array}$ & $\mathrm{F}$ & $\mathrm{p}$ & Diff. \\
\hline \multirow{3}{*}{$\begin{array}{l}\text { Optimism/regulating the } \\
\text { mood }\end{array}$} & Inter-groups & 1683,155 & 8 & 210,394 & \multirow[t]{3}{*}{6,86} & \multirow[t]{3}{*}{00} & $6,8,9>$ \\
\hline & In-group & 17696,961 & 577 & 30,671 & & & $2,4,7$ \\
\hline & Total & 19380,116 & 585 & & & & $8,9>5$ \\
\hline \multirow{3}{*}{ Using the feelings } & Inter-groups & 51,705 & 8 & 6,463 & \multirow[t]{3}{*}{2,48} & \multirow[t]{3}{*}{01} & \multirow[t]{3}{*}{$7>2,4$} \\
\hline & In-group & 1503,061 & 577 & 2,605 & & & \\
\hline & Total & 1554,766 & 585 & & & & \\
\hline \multirow[t]{3}{*}{ Evaluating the feelings } & Inter-groups & 166,331 & 8 & 20,791 & \multirow[t]{3}{*}{4,02} & \multirow[t]{3}{*}{,00 } & \multirow[t]{3}{*}{$9>2,3,4$} \\
\hline & In-group & 2979,417 & 577 & 5,164 & & & \\
\hline & Total & 3145,747 & 585 & & & & \\
\hline \multirow{3}{*}{$\begin{array}{l}\text { Total emotional intelligence } \\
\text { score }\end{array}$} & Inter-groups & 7130,622 & 8 & 891,328 & \multirow[t]{3}{*}{9,26} & \multirow[t]{3}{*}{00} & $8>$ \\
\hline & In-group & 55516,811 & 577 & 96,216 & & & $1,2,3,4,5,7$ \\
\hline & Total & 62647,433 & 585 & & & & $\begin{array}{c}9>2,3,4,7 \\
6>2,4\end{array}$ \\
\hline
\end{tabular}

1. Artisan, 2. Driver, 3. Religious officers, 4. Worker, 5. Security personnel, 6. Healthcare personnel, 7. Auto industry employee, 8. Preschool teacher, 9. Special education teacher

Considering the table 5, one way variance (ANOVA) analysis technique was applied for comparing the profession groups of the participants according to the emotional intelligence scores. It was seen that there is statistically significant difference in the optimism/regulating the mood, using the emotions, evaluating the feelings, and total emotional intelligence scores according to the profession groups of the participants $(\mathrm{p}<0.05)$. According to the results of the Post Hoc (TUKEY) test, performed for determining the significant difference is between which groups, a statistically significant difference was found out between healthcare personnel, preschool teacher and special education teacher and the driver, worker and auto industry employees, on behalf of the healthcare personnel, preschool teacher and special education teacher in the optimism/regulating the mood sub-dimension $(\mathrm{p}<0.05)$. A statistically significant difference was found out between the special education teacher and driver, religious officer and worker, on behalf of the special education teachers and between the security personnel and workers, on behalf of the security personnel in the evaluating the feelings sub-dimension $(\mathrm{p}<0.05)$. On the other hand, a statistically significant difference was found out between preschool teacher and artisan, driver, religious officer, worker, security personnel and auto industry employees on behalf of the preschool teacher, between the special education teacher and driver, religious officer, worker, and auto industry workers, on behalf of the special education teacher and finally between healthcare personnel and driver and worker, on behalf of the healthcare personnel in the total emotional intelligence score $(\mathrm{p}<0.05)$.

\section{Discussion and Conclusion}

In this part of the research, the findings obtained and the information encountered with in the literature are discussed and evaluations are made. When the emotional intelligence scores of the adults in different profession groups are compared according to the gender, a statistically significant difference was found out on behalf of the women in the optimism/regulating the mood, evaluating the feelings and total emotional intelligence score $(\mathrm{p}<0.05)$. Özdemir and Tokol (2008) stated that women, thanks to the estrogen and oxytocin hormone, found in women, have more self-confidence, are more determined and these traits trigger their instinct for interpersonal interaction. These notions may be related with the emotional intelligence. Brody and Hall (1993), in the research they made, stated that the language skill of girls develops earlier than the males and as a result of this, girls become skilled quickly compared with 
males in making emotional analysis. It can be said that, the girls, living more intensely their emotional states, turn into individuals who can analyze and assess their emotions better. This transformation may bring the women to a more successful point in the professions they execute. Kelan (2008) the social adequacies and emotional statuses of the workers gained an important place with respect to the work performance when referring the working employees with regards to the gender. This situation emerged a difference between two genders. It was found out that when men executing any work, they are expected to establish an emotional empathy with the other employees, but men only see this empathy situation as one of the factors necessary for doing a work. It was stated that women apply these traits more easily in their careers and this situation is a natural trait for women. This natural trait may be arisen from the physiological differences accommodated by women in them. The conclusion obtained indicates that the gender difference is important in the professions. For example, according to the research made by Khan and Vieito (2013), the companies with women CEO carry less risk factor. There may be a connection between women having high emotional intelligence level and the decrease in the risk factor.

No statistically significant difference was found out in the emotional intelligence sub-dimension and total score compared with sporting situation of the participants $(\mathrm{p}>0.05)$. Considering the researches done related with participating in the physical activity, it is thought that the situations such as fast development of the technology, economic growth, and urbanization ratio indicating increase cause that individuals become sedentary. The result revealed that these factors, causing that people have sedentary lives are seen more in the developed countries together with the new diseases (Branca et al., 2007; Guthold et al., 2008). This situation emerged may be because the work load on individuals increases or the working hours are too much. The emotional status of the employees may deteriorate in parallel with this. It is seen that $24 \%$ of the participants, consisting of our work group, from different occupation groups, play sports and $76 \%$ doesn't participate in the sport activities. Aligned with our research finding, the sporting situations of 293 Polish office employees were assessed and it was seen that 70\% has low participation in sports (Biernat et al., 2010). Furthermore, this situation was encountered with in different countries and it was stated that sporting situation showed more decrease in the recent years. Even though there are places where there are adequate sporting means, it is seen that only $10 \%$ of the people play sports and this number is very small compared with the European countries (Karahüseyinoğlu et al., 2005). The increase in the work load of the employees with the growing business sectors causes a decrease in the playing sport situations. Because of this, providing means for physical activity, increasing free times is one of the important issues (Branca et al., 2007). It was stated by the scientists that playing sports positively affects the individuals physiologically and psychologically (Küçük and Koç, 2004; Sarıkabak, 2018). While being in different physical activities or interests cause that the adults, executing their professions, are well spiritually, it is thought that this may cause increase in the professional performance too.

It is seen that there is a statistically significant difference in the using the feelings, evaluating the feelings, and total emotional intelligence scores according to the age groups of the individuals from different occupation groups $(\mathrm{p}<0.05)$. This significant difference emerged can be seen in the age groups which we can call as the first adulthood and old age. These age intervals were observed as 18-23, 24-29 with 42-47, 48 and over. The individuals, while performing their professional responsibilities, may face with negative situations with the increasing age. While the young employees indicate tendencies like solving and understanding this situation, the employees with advanced age may select to alienate from this situation. This event affects the mental health of the employees negatively and may cause exhaustion (Qunian, 2007:386). Güllüce and İşcan (2010:20), in the research they made for evaluating the relationship between occupational exhaustion and emotional intelligence, obtained results similar to our research findings. Güllüce and İşcan (2010:20) observed increase in the occupational exhaustion levels of the employees, 51 years old and over.

It is seen that there is statistically significant difference in the optimism/regulating the mood, using the feelings, evaluating the feelings, and total emotional intelligence scores according to the profession groups $(\mathrm{p}<0.05)$. Aslantaş (2006:63), in the research he made, obtained significant differences in the optimism/regulating the mood sub-dimension at the emotional intelligence levels of the preschool teachers. It is seen that the preschool teachers state their emotions by mostly using optimist emotional situations, without noticing the emotions (Arslantaş, 2006:63). It is one of the remarkable issues that there is small number of researches, where special education teachers are evaluated with respect to their emotional intelligence levels, in the literature. Because the special education teachers have to manage by liking harder and more comprehensive processes, it can be expected that their emotional intelligence level is high. It can be accepted as the reason for the increase in this level that there is human communication in the foundation of teaching, the students are approached by developing empathy and it is tried that they are better mentally (Girgin and Baysal 2005; Eripek, 2002; Yin, Lee and Zhang, 2013). These notions also have close relationship with the emotional intelligence notion. Another finding is that the optimism/regulating the mood sub-dimension create a significant difference on behalf of the healthcare personnel compared with the other profession groups. Healthcare personnel encounter with a lot of positive and negative situations. We know that the emotional states, reflecting sadness and joy, with respect to the 
human life, are conveyed by the healthcare personnel to the people. Healthcare personnel, when approaching the respondents, encounters with the situations carrying risk factor more, compared with the other profession groups. It is expected that the ones working in the healthcare sector contact with the patients with a more optimistic approach, without using the words which may insult the people with which they are in communication. This situation may be one of the reasons that optimism/regulating the mood sub-dimension form a significant difference with respect to the healthcare personnel. Onay and Uğur (2011) emphasized that emotional intelligence is an important notion with respect to the healthcare personnel. They remarked that it is important with regards to the healthcare personnel to establish a better relation with the patients, to understand them, and the skill to guide the feelings of the patients when providing care and diagnosing. The healthcare personnel, usually wanted to be investigated with studies where the emotional intelligence notion is always at the forefront in order to understand the mood of the patients and manage their feelings (Büyükbayram and Gürkan, 2014; Psilopanagioti et al., 2012; Saeid, Javadi and Sirati, 2013).

Another finding of our research is that the difference between the auto industry employer and worker occupations is in favor of the auto industry employees in the using the feeling sub-dimension. This significant difference may be arisen from the auto industry employees coming together with people from all occupations and establishing a strong relationship. Because the auto industry employees have to use their feelings professionally when trying to understand the problems of the people with which they are in communication and to find solutions to these problems, it was supported by the researches made that this necessity affects the emotional intelligence levels positively. At the same time, the researchers found out a significant and linear relationship with the work performance and human relations with the emotional intelligence level (Horasan et al., 2018; Öçal, 2016). Öçal, (2016), in his postgraduate thesis he made, researched the relation of the value chain activities and emotional intelligence level of the individuals working in the Doğuş Automotive company and found significant differences with respect to the emotional intelligence levels of the employees.

As a result of the research, we can say that emotional intelligence is a very important notion affecting the work performance and human relationships in all occupation groups. It is seen that, among the profession groups, in general the emotional intelligence scores are higher in the teachers. At the same time, it is seen that the sporting situation is affective on the individuals who execute their professions however no significant difference was obtained related with sporting situation in our findings. It was seen by the researchers that participation of the individuals to the higher level sport activities support the work performance and emotional intelligence level in a significant direction.

The adult individuals in different profession groups need to aware of the sides which are strong and can be improved, to be able to manage their emotional states, besides to understand the feelings and thoughts of the friends they work together and the persons in their lives in order to achieve happiness in every moment of their lives. The individuals, when they are happy in the work environment, can assist the institution for which they work at the top level. The employee, in order to aware their emotional intelligence levels and to increase their emotional intelligence level, may be recommended to prepare ambiances where they can pass their free times entertaining and efficiently.

It can be recommended that the importance of the sportive activity and the importance of the emotional intelligence is conveyed to the employees via various training seminars by the companies. It should not be ignored that higher the emotional intelligence level of the employees the success can be obtained in the human relationships proportionally. It can be recommended that the emotional intelligence researches are applied to more various and bigger sampling groups.

\section{References}

Aktürk, Y. (1983). Beşinci Beş Yıllık Kalkınma Planı Gençlik ve Spor Özel İhtisas Komisyonu, Spor Komisyon Raporu. T.C. Başbakanlık Devlet Planlama Teşkilatı Müsteşarlığı. Ankara

Arslantaş, H. (2006). The Emphatetic Tendecy Level and Emotional Intelligence Level of Pre-School Teachers . Yüksek Lisans Tezi. Kahramanmaraş Sütçü İmam Üniversitesi, Kahramanmaraş.

Austin, E. J., Saklofske, D. H., Huang, S. S., \& McKenney, D. (2004). Measurement of Trait Emotional Intelligence: Testing and Cross Validating A modified Version of Schutte Et Al's (1998) Measure. Personality Indviduals Different, 36(3), 555-562. https://doi.org/10.1016/S0191-8869(03)00114-4

Bar-On, R. (2005). The Impact of Emotional Intelligence on Subjective Well-Being. Perspectives in Education, 23(1), 41-62.

BIBLIOGRAPHY Karahüseyinoğlu, M., Ramazanoğlu, F., Nacar, E., Savucu, Y., Ramazanoğlu, O., \& Altungül, O. (2005). Türkiye'nin Spordaki Konumunun Bazı Avrupa Ülkeleri ile Karşılaştırılması. Doğu Anadolu Bölgesi Araştırmaları, 3(3), 75-82.

Biernat, E. P., Tomaszewski, P., \& Milde, K. (2010). Physical Actıvity of Office Workers. Biology of Sport, 27(4), 289-296. https://doi.org/10.5604/20831862.927495 
Branca, F., Nikogosian, H., \& Lobstein, T. (2007). The Challenge of Obesity in The WHO European Region and The Strategies for Response: Summary. World Health Organization.

Brody, L. R., \& Hall, J. A. (1993). Gender and emotion. Handbook od Emotions.

Büyükbayram, A., \& Gürkan, A. (2014). The Role of Emotional Intelligence in Job Satisfaction of Nurses. Journal of Psychiatric Nursing, 5(1), 41-49. https://doi.org/10.5505/phd.2014.50470

Büyüköztürk, Ş., Çakmak, E. K., Akgün, Ö. E., Karadeniz, Ş., \& Demirel, F. (2017). Scientific Research Methods. Pegem Citation Index, 1-360.

Cole, M. L., Cox, J. D., \& Stavros, J. M. (2018). SOAR as a Mediator of the Relationship Between Emotional Intelligence and Collaboration Among Professionals Working in Teams: Implications for Entrepreneurial Teams. SAGE Open, 8(2), 1-12. https://doi.org/10.1177/2158244018779109

Corcoran, R. P., \& Tormey, R. (2012). Assessing Emotional Intelligence and its Impact in Caring Professions: The Value of a Mixed-Methods Approach in Emotional Intelligence Work with Teachers. In Emotional Intelligence-New Perspectives and Applications. IntechOpen, 216-238.

Eripek, S. (2002). Özel Eğitim. Anadolu Üniversitesi.

Girgin, G., \& Baysal, A. (2005). Zihinsel Engelli Öğrencilere Eğitim Veren Öğretmenlerin Mesleki Tükenmişlik Düzeyi ve Bazı Değişkenler (İzmir Örneği). Pamukkale Üniversitesi Ĕ̆itim Fakültesi, 18(18), 1-10.

Goleman, D. (1996). Emotional Intelligence: Why It Can Matter More Than IQ. London: Cox \& Wyman Ltd.

Güllüce, A. Ç., \& İşcan, Ö. F. (2010). Mesleki Tükenmişlik ve Duygusal Zeka Arasındaki İlişki. Eskişehir Osmangazi Üniversitesi IIBBF Dergisi, 5(2), 7-29.

Guthold, R., Ono, T., Strong, K. L., Chatterji, S., \& Morabia, A. (2008). Worldwide Variability in Physical İnactivity: A 51- Country Survey. American Journal of Preventive Medicine, 34(6), 486-494. https://doi.org/10.1016/j.amepre.2008.02.013

Horasan, İ., Turan, M. Ş., Kazaz, B., Yöndem, A., \& Miman, Ö. M. (2018). Demografik Özelliklerin Duygusal Zeka Seviyelerine Etkilerinin Araştırılması: Otomotiv ve Elektrikli El Aletleri Sekteründe Bir Çalışma Öz. The Journal of Academic Social Science, 6(72), 560-576. https://doi.org/10.16992/ASOS.13811

Johson, D. R. (2015). Emotional Intelligence as a Crucial Component to Medical Education. International Journal of Medical Education, 6, 179. https://doi.org/10.5116/ijme.5654.3044

Karademir, T., \& Çoban, B. (2011). Spor Alanında Örgütsel Adalet ve Duygusal Zeka. Elektronik Sosyal Bilimler Dergisi, 10(36), 25-41.

Kelan, E. K. (2008). Emotions in a Rational Profession: The Gendering of skills in ICT Work. Gender, Work and Organization, 15(1), 49-71.

Khan, W. A., \& Vieito, J. P. (2013). CEO Gender and Firm Performance. Journal of Economics and Business, 67, 55-66. https://doi.org/10.1016/j.jeconbus.2013.01.003

Kosti, M. V., Feldt, R., \& Angelis, L. (2014). Personality Emotional Intelligence and Work Preferences in Software Engineering: An Emprical Study. Information and Software Technology, 56(8), 973-990. https://doi.org/10.1016/j.infsof.2014.03.004

Küçük, V., \& Koç, H. (2004). Psiko-sosyal Gelişim Süreci İçerisinde İnsan ve Spor İlişkisi. Dumlupınar Üniversitesi Sosyal Bilimler Dergisi, 10.

Littlejohn, P. (2012). The Missing Link: Using Emotional Intelligence to Reduce Workplace Stress and Workplace Violence in Our Nursing and Other Health Care Professions. Journal of Professional Nursing, 28(6), 360-368. https://doi.org/10.1016/j.profnurs.2012.04.006

Maguire, J. A. (2018). Social Sciences in Sport. Human Kinetics.

Menevse, A. (2018). The Effect of Physical Education and Sports Departments on Behavioral Changes Towards Exercising. Educational Research and Reviews, 13(13), 518-525. https://doi.org/10.5897/ERR2018.3499

Öçal, E. (2006). The relationship between value chain activities and demographic factors with emotional intelligence: Doğuş Otomotiv case. Marmara Üniversitesi, İstanbul.

Onay, M., \& Uğur, B. (2011). Sağlıktaki Memnuniyetin Sessiz Sihri "Duygusal Zeka". Organizasyon ve Yönetim Bilimleri Dergisi, 3(2), 23-34.

Özdemir, E., \& Tokol, T. (2008). Marketing Strategies for Women Consumers. Anadolu University Journal of Social 
Sciences, 8(2), 57-80.

Paul, S. (2015). Effect of Neuroticism and Sports Participation on Emotional Intelligence of Female Players \& non-players. Academic Sports Scholar, 4(3), 1-3.

Psilopanagioti, A., Anagnostopoulos, F., Mourtou, E., \& Niakas, D. (2012). Emotional Intelligence, Emotional Labor and Job Satisfaction Among Physicians in Greece. BMC Helath Services Research, 12(1), 463. https://doi.org/10.1186/1472-6963-12-463

Quinlan, M. (2007). Organisational Restructing/Downsizing, OHS Regulation and Worker Health and Wellbeing. International Journal of Law and Psychiatry, 30(4-5), 385-399. https://doi.org/10.1016/j.ijlp.2007.06.010

Rahman, F. A., Sugiyanto, S., \& Kristiyanto, A. (2018). Benefits Recreational Sports of Mountain Climbing for Physical Health, Psychology, Social and Spiritual. International Journal of Multicultural and Multireligious Understanding, 5, 43-48. https://doi.org/10.18415/ijmmu.v5i5.292

Saeid, Y., Javadi, M., \& Sirati Nir, M. (2013). On The Relationship Between Emotional Intelligence and Demographical Variables in Nurses. Journal of Military Medicine, 15(1) 87-92.

Salovey, P., \& Mayer, J. D. (1990). Emotional Intelligence. Imagination, Cognition and Personality, 9(3), $185-211$. https://doi.org/10.2190/DUGG-P24E-52WK-6CDG

Sarıkabak, M. (2016). Olumlu ve Olumsuz Geri Bildirimin, Farklı Kişilik Tiplerindeki Sporcularda, Biceps Brachii Kasınan Maksimal İstemli Kasılma Seviyesi Üzerine Etkisi. Sakarya Üniversitesi, Sakarya: Doktora Tezi.

Sarıkabak, M. (2018). Duygusal Zeka ve Spor. F. Yamaner, \& E. Eyuboğlu, içinde, İnsan, Toplum ve Spor Bilimleri Araştırma Örnekleri Kitabı (s. 401-409). Nobel Akademik Yayıncılık.

Sarıkabak, M., Eyuboğlu, E., \& Ayrancı, M. (2018). Investigation of the Effect of Emotional Intelligence Levels of Bocce (Petanque) Athletes on Academic Procrastination Behaviors. International Journal of Cultural and Social Studies, 4(1), 160-177.

Sarıkabak, M., Recep, A. A., \& Ayranc1, M. (2018). Examining Views of Primary School Children Aged 6-7 on Sports. CBÜ Beden Ĕ̈itimi ve Spor Bilimleri Dergisi, 13(2), 405-417. https://doi.org/10.33459/cbubesbd.480842

Schutte, N. S., Malouff, J. M., Hall, L. E., Haggerty, D. J., Cooper, J. T., \& Golden, C. J. (1998). Decelopment and Validation of a Measure of Emotional Intelligence. Pers Indiv Differ, 25(2), 167-177. https://doi.org/10.1016/S0191-8869(98)00001-4

Seçer, H. Ş. (2007). Mesleki Yaşam Modelinin Oluşturulması ve Mesleki Analizlerde Kullanımı. Doktora Tezi. Dokuz Eylül Üniversitesi, İzmir.

Szabo, A., Griffiths, M. D., \& Demetrovics, Z. (2019). Psychology and exercise. In. Nutrition and enhanced sports performance, 63-72. https://doi.org/10.1016/B978-0-12-813922-6.00005-9

Tatar, A., Tok, S., \& Saltukoğlu, G. (2011). Adaptation of the Revised Schutte Emotional Intelligence Scale into Turkish and Examination of its Psychometric Properties. Bulletin of Clinical Psychopharmacology, 24(4), 325-338. https://doi.org/10.5455/bcp.20110624015920

Thapa, S. K., Baro, M., Singh, O. J., Changmai, S., \& Gogoi, B. C. (2018). Journal of Advances in Sports and Physical Education. Scholars Middle East Publishers, 72-73.

Vurucu, F. (2010). Meslek Lisesi Öğrencilerinin Meslek Seçimi Yeterliliği ve Meslek Seçimini Etkileyen Faktörler. Yayınlanmamış Yüksek Lisans Tezi. Yeditepe Üniversitesi, İstanbul.

Yin, H. B., Lee, J. K., \& Zhang, Z. H. (2013). Exploring the Relationship Among Teachers Emotional Intelligence, Emotional Labor Strategies and Teaching Satisfaction. Teaching and Teacher Education, 37, 137-145. https://doi.org/10.1016/j.tate.2013.06.006

Zizzi, S., Deaner, H., \& Hirschhorn, D. (2003). The Relationship Between Emotional Intelligence and Performance Among College Basketball Players. Journal of Applied Sport Psychology, 15(3), 262-269. https://doi.org/10.1080/10413200305390

\section{Copyrights}

Copyright for this article is retained by the author(s), with first publication rights granted to the journal.

This is an open-access article distributed under the terms and conditions of the Creative Commons Attribution license which permits unrestricted use, distribution, and reproduction in any medium, provided the original work is properly cited. 